\title{
Analysis of chemical constituents and antinociceptive potential of essential oil of Teucrium Stocksianum bioss collected from the North West of Pakistan
}

Syed Muhammad Mukarram Shah ${ }^{1}$, Farhat Ullah' ${ }^{1 *}$, Syed Muhammad Hassan Shah², Mohammad Zahoor ${ }^{3}$ and Abdul Sadiq ${ }^{1}$

\begin{abstract}
Background: Medicinal plants are used for the treatment of different diseases in almost all cultures. Teucrium species grow wildly at different geographical locations around the world. Teucrium stocksianum is used in folk medicine for the treatment of diarrhea, cough, jaundice and abdominal pain. Scientific study on Teucrium stocksianum shows that it possesses anthelmintic, cytotoxic and antispasmodic activity. The aim of our present study is to identify the chemical composition and antinociceptive potential of the essential oil extracted from Teucrium stocksianum bioss.
\end{abstract}

Method: Essential oil (EO) from the aerial parts of Teucrium stocksianum were extracted by hydrodistillation process. The qualitative and quantitative composition of essential oil was determined with Gas chromatography/Mass spectrometer. Antinociceptive activity was determined by acetic acid induced writhing method. Percent inhibition of writhes of the test concentration was determined by comparing it with that of control. Tween-80 emulsion 2.5\% $(5 \mathrm{ml} / \mathrm{kg}$ b.w) was used as a control while Diclofenic sodium $50 \mathrm{mg} / \mathrm{kg}$ (b.w) was used as a standard drug.

Results: The chromatogram of the essential oil of Teucrium stocksianum shows differences both qualitatively and quantatively from essential oil composition reported in other countries. Hydrodistillation of Teucrium stocksianum yielded $0.4 \%(\mathrm{~V} / \mathrm{W})$, pale yellowish oil on dry basis. A total of 26 chemicals were identified by GC-MS accounting for $90.28 \%$ of the oil. The major components of essential oil were $\delta$-cadinene $(12.92 \%)$, a-pinene (10.3\%), myrcene (8.64\%), $\beta$-caryophyllene (8.23\%), germacrene D (5.18\%) and limonene (2.36\%). Essential oil of Teucrium stocksianum has shown outstanding antinociceptive activity. It has been observed that increase in percent writhe inhibition (PWI) occurred from 20-80 mg/kg (b.w) and maximum writhe inhibition has been noted at a concentration of $80 \mathrm{mg} / \mathrm{kg}$ (b.w), but PWI decreased at $160 \mathrm{mg} / \mathrm{kg}$, which may be due to some toxic effect of higher dose. $\mathrm{ED}_{50}$ value for Teucrium stocksianum was calculated as $31.5 \pm 1.72415 \mathrm{mg} / \mathrm{kg}$ (b.w).

Conclusion: Our results indicate that there is a lot of variation in the composition of essential oil of Teucrium stocksianum boiss, which may be due to different climatic and experimental conditions. Secondly, the essential oil possesses strong antinociceptive activity and could be used in analgesic preparations especially for topical use.

Keywords: Teucrium stocksianum, Antinociceptive, Essential oil

\footnotetext{
* Correspondence: farhataziz80@hotmail.com

'Department of Pharmacy, University of Malakand, Chakdara Dir, KPK, Pakistan

Full list of author information is available at the end of the article
} 


\section{Background}

Essential oils have been used for therapeutic purposes since ancient times. The Chinese were expert in extraction and use of these oils. Essential oils are produced in specialized ducts called schizogenous ducts in plants. These oils have applications in food industry, fashion and pharmaceutical industry. Such oils have been used as foods preservatives and drugs. Mostly, these are used as topical preparations for analgesics, anti-inflammatory and antimicrobial effects. Nowadays, these are also used as mosquito repellents. All these properties are due to presence of secondary metabolites [1,2].

The genus Teucrium belongs to the family Lamiaceae and contains 340 species. Untill now, 04 species have been reported in Pakistan. Medicinal properties of various species of Teucrium are reported in literature showing antioxidant, antibacterial, antifungal activities [3-7]. Teucrium polium has been reported to possess antispasmodic, antimicrobial, anti-inflammatory, [8], hepatoprotective effect, [9] and analgesic properties [10]. While Teucrium chamaedrys has been used as antimalarial, antispasmodic and for gastric pain, kidney disorders, heart diseases etc $[11,12]$.

Lamiaceae family is rich in essential oils. The main components of the essential oil reported from the genus Teucrium are alpha pinene, linalool, carophyllene oxide, Germacrene D, beta carophyllene and delta cadinene. These phytochemicals possess antimicrobial, cytotoxic, phospholipase, esterase inhibitory properties [13] and can prove very useful leads for novel drug development.

Teucrium stocksianum is a specie found in the North West of Pakistan (Dir, Swat, Malakand, and Hazara). It is a perennial aromatic herb of $10-30 \mathrm{~cm}$ height having grayish-white leaves and sessile flowers. It grows in mountains in shades. This plant is used in folk medicine for treating diarrhea, cough, jaundice and abdominal pain [14]. Due to its uses in traditional medicine system, several scientific studies have been conducted to rationalize and establish its therapeutic potential. Teucrium stocksianum possesses hepatoprotective and gastric cytoprotective properties $[15,16]$. Crude saponins isolated from it have shown cytotoxic and anthelminthic effects [17], while antispasmodic activity has also been reported recently. These scientific studies indicate high medicinal potential of T. stocksianum. Due to its wild growth in nature and presence of valuable phytochemicals in other species of this genus prompted us to determine chemical composition and therapeutic potential on scientific grounds.

\section{Methods}

\section{Plant material}

The aerial parts of T. stocksianum were collected in their full bloom stage from District Dir, in the province of Khyber Pakhtoonkhwa, Pakistan, in May 2012. The plant was dried in shade under suitable condition of temperature in order to avoid any degradation, loss of essential oil and to retain the original colour of the plant. The dried plant was powdered for further use. The plant was identified by Professor Dr Nasrullah, Department of Botany, University of Malakand, Pakistan. A voucher specimen (H.UOM.BG.199) of the whole plant was deposited in the herbarium of the same University.

\section{Essential oil extraction}

The aerial parts of the plant, including inflorescence, small twinges and leaves were cut into small pieces. About $200 \mathrm{~g}$ of it was transferred to Clevenger type apparatus and was hydrodistilled for 3-4 h. At the end we got $0.4 \%(\mathrm{v} / \mathrm{w})$ pale yellowish essential oil based on dried weight of plant. Anhydrous Sodium sulfide $\left(\mathrm{Na}_{2} \mathrm{SO}_{4}\right)$ was used to dry the essential oil, which was stored at $4^{\circ} \mathrm{C}$ before analysis. The essential oil was subjected to GCMS-analysis.

\section{Chemicals and drugs}

All chemicals used in this study were of analytical grade purchased from Merck, Pakistan. Diclofenic sodium was obtained from Sigma.

\section{Statistics and calculations}

One-way analysis of variance (ANOVA) and Tukey's multiple comparison test was applied for the comparison among various groups. Differences with $P \leq 0.05$ and lower between groups were considered significant.

\section{Gas chromatography-mass spectrometry}

The components of the EO were analyzed using GCMSQP 2010 (Tokyo, Japan), with an auto-injector (AOC-20i) and auto-sampler (AOC-20s). Sample was eluted with Helium gas. Components were separated with capillary column (DB-5MS Prepared by Agilent Technology USA) having $30 \mathrm{~m}$ length, $0.250 \mathrm{~mm}$ internal diameter and 0.25 micro meter thickness. Electron impact ionization mode with energy $70 \mathrm{ev}$, ion source temperature $250^{\circ} \mathrm{C}$, interface temperature $240^{\circ} \mathrm{C}$ with $80 \mathrm{KPa}$ pressure, $1.8 \mathrm{~min}$ solvent cut time. Injector temperature was $250^{\circ} \mathrm{C}$ and operated in split mode with $1 \mathrm{ml} / \mathrm{min}$. The column was programmed at a temperature of $50^{\circ} \mathrm{C}$ for $1 \mathrm{~min}$ initially and then changed to $150^{\circ} \mathrm{C}$ at the rate of $15^{\circ} \mathrm{C} / \mathrm{min}$ and kept constant $15 \mathrm{~min}$. The column temperature was increased to $280^{\circ} \mathrm{C}$ at a rate of $2.5^{\circ} \mathrm{C}$ per min and was maintained for $3 \mathrm{~min}$. Mass spectra were acquired in the range of 40 to $650 \mathrm{~m} / \mathrm{z}$. A series of normal alkanes was also injected under same analytical conditions with that of the essential oil for the calculation of Retention Indices. Components of the essential oil were identified by comparing the mass spectra obtained with those of standard mass 
spectra from the NIST library (NIST 05). Relative concentration of the components was calculated from the peak areas of the total ion chromatograms.

\section{Animals}

Swiss Albino mice of either sex, weighing between 20$30 \mathrm{~g}$ of approximately same age were used for the present study. Animals were kept under controlled laboratory conditions on 10/14 h light and dark period with free access to laboratory diet and water. All animals were fasted for $24 \mathrm{~h}$ before the test. Animal's studies were performed according to the Scientific Procedures Issue-1 of Animal Bylaws-2008 approved by the legal bodies of the University of Malakand Khyber Pakhtoonkhwa, Pakistan. The ethical committee of the department of pharmacy granted approval for conducting this study under the said protocols (Procedures Issue-1 of Animal Bylaws-2008).

\section{Antinociceptive activity}

Acetic acid induced writhing test; Swiss Albino mice of both sexes were divided into five groups, each including six animals. $2.5 \%$ Tween- 80 solution $(10 \mathrm{ml} / \mathrm{kg})$ was administered intraperitoneally to control group. Test groups were treated with an emulsion of Teucrium stocksianum essential oil of Tween-80 (2.5\% v/v, water as a vehicle), at a dose of $20-160 \mathrm{mg} / \mathrm{kg}$ and standard group received intraperitoneal injection of $50 \mathrm{mg} / \mathrm{kg}$ dose of Diclofenic sodium. After $30 \mathrm{~min}, 0.6 \%$ acetic acid $(15 \mathrm{ml} / \mathrm{kg})$ was injected through the same route. Total writhes produced in each mouse were noted for $20 \mathrm{~min}$ immediately after injection of acetic acid. Antinociception was determined by reduction of writhing numbers by comparing the number of writhes produced in the control group treated with Tween- 80 and to that of test groups treated with Teucrium stocksianum essential oil doses of $20-160 \mathrm{mg} / \mathrm{kg}$ [18].

\section{Results and discussion}

In this study, hydrodistillation of the aerial parts of $T$. stocksianum gave pale yellow coloured essential oil having a pleasant aromatic smell. Yield of the oil was about $0.4(\mathrm{v} / \mathrm{w})$ on a dry weight basis. A total of 26 chemicals were identified by GC-MS accounting for $90.28 \%$ of the oil, given in the Table 1 . Constituents of essential oils vary with geographic location, collection time and parts of plants used for oil extraction. Bagci et al. have reported 36 chemicals from $T$. chamaedrys collected from Turkey [19] while Morteza-Semmani $\mathrm{K}$ et al. reported 49 chemical constituents from the essential oil of same specie from Iran [20]. Yousuf et al., have reported differences in the number of chemicals and relative concentration of chemicals in the same specie from same geographic location, but collected in different
Table 1 Percentage composition of the essential oil from the aerial part of Teucrium stocksianum Bioss

\begin{tabular}{|c|c|c|c|}
\hline Compound No. & $\begin{array}{l}\text { Compound } \\
\text { Name }\end{array}$ & $\begin{array}{l}\text { Retention } \\
\text { Indices }\end{array}$ & Percentage \\
\hline 1 & a Pinene & 943 & 10.3 \\
\hline 2 & Sabinene & 971 & 2.6 \\
\hline 3 & $\beta$ Pinene & 986 & 2.82 \\
\hline 4 & Myrcene & 1008 & 8.64 \\
\hline 5 & a Terpinene & 1020 & 1.21 \\
\hline 6 & Cymene & 1030 & 0.85 \\
\hline 7 & Limonene & 1041 & 2.36 \\
\hline 8 & Terpineol & 1146 & 0.49 \\
\hline 9 & Linalool & 1108 & 1.75 \\
\hline 10 & Myrienal & 1210 & 2.75 \\
\hline 11 & Bornyl acetate & 1292 & 1.58 \\
\hline 12 & $\beta$ Myrcene & 1303 & 1.64 \\
\hline 13 & 6 Elemene & 1345 & 2.95 \\
\hline 14 & a Cubebene & 1359 & 1.72 \\
\hline 15 & a Copaene & 1385 & 1.51 \\
\hline 16 & $\beta$ Cubebene & 1404 & 0.53 \\
\hline 17 & $\beta$ Caryophyllene & 1427 & 8.23 \\
\hline 18 & a Guaiene & 1445 & 2.53 \\
\hline 19 & a Humulene & 1462 & 2.81 \\
\hline 20 & Seychellene & 1479 & 6.72 \\
\hline 21 & Germacrene D & 1488 & 6.18 \\
\hline 22 & $\curlyvee$ Cadinene & 1519 & 2.86 \\
\hline 23 & 6 Cadinene & 1535 & 12.92 \\
\hline 24 & Spathulenol & 1558 & 1.35 \\
\hline 25 & Elemol & 1557 & 2.13 \\
\hline \multirow[t]{2}{*}{26} & Caryophyllene oxide & 1590 & 0.85 \\
\hline & Total & & 90.28 \\
\hline
\end{tabular}

$R I=$ Retention indices.

years [21]. Sesquiterpenes (59\%) were found more than monoterpenes $(40.97 \%)$ in this study. Other studies done on Tecucrium genus have also recorded more sesquiterpenes than the monoterpenes in their essential oils $[19,22]$. Relative concentration of different major components observed in our study are, $\delta$-cadinene $(12.92 \%)$, $\alpha$-pinene $(10.3 \%)$, myrcene $(8.64 \%), \quad \beta$-caryophyllene (8.23\%), germacrene D (5.18\%), limonene (2.36\%), elemol (2.13\%), $\gamma$-cadinene (1.86\%). While comparing relative concentration of different components of the essential oil from same specie, we recorded $\delta$-cadinene to be $12.92 \%$ while Yousuf et al. have recorded $13.8 \% \delta$ cadinene from UAE [21], which is almost the same value. It is to be noted that major chemical constituent of our study is $\delta$-cadinene in contrast to Yousuf et al. and Jaimand et al., who have recorded $\alpha$-cadinol (14.6\%) and camphene (20.6\%) as the major constituents in the 
United Arab Emirates (UAE) and Iran respectively $[21,23]$. Literature shows great variation in the concentration of $\alpha$-pinene in the Tecucrium genus. In our study, $\alpha$-pinene was the second most abundant component while Moghtader et al. from Iran has reported the same component to be $12.52 \%$ as the major one in their study on the essential oil of Teucrium stocksianum [24]. In contrast, Nasser et al. from Yemen and Bagci et al. from Turkey have reported $\alpha$-pinene, $0.96 \%$ and $0.2 \%$ respectively $[19,25]$. It is worth noting that Jaimand et al. from Iran and Yousuf et al. from the United Arab Emirate (UAE) haven't found this component in their work $[21,23]$. Germacrene D, a common sesquiterpene, has been found by researchers from the genus Teucrium genus from different countries like Iran (10.2\%) [26], Jordan (4.3\%) [27], Italy (18\%) [28] and Portugal (21.6\%) [29]. This compound may be a precursor for the biosynthesis of various sesquiterpenes like cadinenes and selinenes [30] and is insecticidal against mosquitoes [31]. We found it to be $5.18 \%$ in our study.

Scientific studies are conducted globally to evaluate antinociceptive efficacy of essential oils. The data from such studies shows that essential oils of various plants containing chemical constituents exert good antinociceptive effects through various mechanisms [32]. Although medicinal plants are often tested for their therapeutic effect as a whole in experiments, studies are available in which single chemical constituents have been tested. Him et al. and Ozbek et al. have evaluated a positive analgesic effect of alpha pinene in their study $[33,34]$. Similarly analgesic activity of myrcene [35], limonene [36], linalool [37] and caryophyllene oxide [38] have been observed.

The chemical method i.e, acetic acid induced writhing protocol is most commonly used for evaluating antinociceptive activity of medicinal plants. Prostaglandins, initially PGE2 and then PGF2 $\alpha$ and free arachidonic acid are released from tissue phospholipids and consequently their levels in the peritoneal fluids increase due to intraperitoneal administration of the irritant, acetic acid. This results in localized inflammatory response and pain sensation due to increase in capillary permeability. Substances which counteract this phenomenon, exert antinociceptive effect and reduce pain sensation [39]. A plethora of studies is available which conclude antinociceptive activity of essentials oils of medicinal plants [40-42]. Various species of the genus Teucrium possess antinociceptive activity $[10,25,43]$. Abdollahi et al. in 2004 conducted a study in Iran and concluded that essential oil was the main contributor in antinociceptive activity [10]. In our study, the essential oil of Teucrium stocksianum significantly inhibited the number of abdominal constrictions induced by acetic acid (Table 2). The essential oil at a dose of $20 \mathrm{mg} / \mathrm{Kg}$, decreased
Table 2 Antinociceptive effect of essential oil of Teucrium stocksianum bioss on abdominal writhing in mice indused acetic acid abdominal injection

\begin{tabular}{llll}
\hline Dose $(\mathbf{m g} / \mathbf{k g})$ & $\mathbf{N}$ & $\begin{array}{l}\text { Number of wriths in } \mathbf{2 0 ~ m i n} \\
\text { (mean } \pm \text { S.D) }\end{array}$ & \% Inhibition \\
\hline $\begin{array}{l}\text { Control }(10 \mathrm{ml} / \mathrm{kg}) \\
\text { Essential oil }\end{array}$ & 6 & $58 \pm 5.600$ & \\
20 & 6 & $30.333 \pm 2.42212$ & $47.701^{* *}$ \\
40 & 6 & $9.6667 \pm 2.16025$ & $83.333^{* *}$ \\
80 & 6 & $3.5000 \pm 1.64317$ & $93.965^{* *}$ \\
160 & 6 & $17.5000 \pm 3.50714$ & $69.827^{* *}$ \\
Diclofenic sodium & 6 & $17.3333 \pm 3.55903$ & $70.115^{* *}$ \\
\hline
\end{tabular}

$N$ : Number of animal per group. D.Sod: Diclofenic Sodium. Percent inhibition was calculated in comparison to control. $F=190.486$, d.f. $=35$. $\mathrm{ED}_{50}$ for analgesic effect of essential oil was $31.5 \pm 1.72415 \mathrm{mg} / \mathrm{kg}$ (b.w). The significance showed by ** $P \leq 0.05$.

writhing by $47 \%$ ( $p$ value $<0.001$ ), at $40 \mathrm{mg} / \mathrm{Kg} 83 \%(p$ value $<0.001$ ), at $80 \mathrm{mg} / \mathrm{Kg} 93 \%$ ( $p$ value $<0.001)$ and at $160 \mathrm{mg} / \mathrm{Kg} 69 \%$ ( $p$ value $<0.001$ ) writhing were inhibited. The positive control used Diclofenic sodium at $50 \mathrm{mg} / \mathrm{Kg}$ inhibited $70 \%$ writhing. Thus, the essential oil in our study had strong activity than the positive control at doses above $40 \mathrm{mg} / \mathrm{Kg}$. Essential oil of Teucrium stocksianum is a combination of various components as shown in Table 1, in which alpha pinene, myrcene, limonene, linalool and caryophylene oxide are present in reasonable concentrations and all these components possess antinociceptive effect. High potency of essential oil of Teucrium stocksianum as compared to Diclofenic sodium may be due to the synergistic effect of the various components present in the essential oil.

The results of antinociceptive effect of our study are similar to that of essential oil extracted from Teucrium polium with respect to antinociceptive potential. T stocksianum caused 93\% writh inhibition at a dose of $80 \mathrm{mg} / \mathrm{kg}$, while $T$ polium produced similar effect (90.22\%) at a dose of $75 \mathrm{mg} / \mathrm{kg}$ (Abdollahi, Karimpour et al. 2003;). This resemblance may be due to qualitative and quantitative similarities in the chemical composition of the essential oil of the two species. Furthermore Teucrium stocksianum is abundantly available in the North West of Pakistan and it grows wildly. It is commonly used in the folk medicinal system of this region. Our study has explored a new source of a very potent and economic analgesic. Such type of studies in which indigenous resources are used would not only provide effective and economical remedies but would also help in poverty reduction of the region.

\section{Conclusion}

Our result pertaining to the composition of essential oil has shown that the composition of the essential oil of the same specie collected from different geographical locations and in different seasons are not the same. 
Essential oil of Teucrium stocksianum has been evaluated by Moghtader et al. from Iran, Nasser et al. from Yeman, Bagic et al from Turky, Yousuf et al. from United Arab emirates (UAE) et al. The results of all these researcher shows a lot of qualitative and quantitative variation in composition (19-21).

Furthermore, essential oil of Teucrium stocksianum possesses a strong antinociceptive potential, which needs further scientific investigation for the rational use as a topical analgesic.

\section{Competing interests}

The authors declare that they have no competing interests.

\section{Authors' contributions}

SMMS carried the practical work, SHS and MZ conceived the idea and did literature survey, FU, SMMS and AS drafted the manuscript. All authors read and approved the final manuscript.

\section{Acknowledgments}

All authors are thankful to the Professor Dr Muhammad Rasul Jan, the Vice Chancellor of University of Malakand, Khyber Pakhtoonkhwa, Pakistan, for providing funds for this project. We are also thankful to Dr Nasrullah Professor Department of Botany of the same University for helping us in the identification of the plant.

\section{Author details}

'Department of Pharmacy, University of Malakand, Chakdara Dir, KPK, Pakistan. ${ }^{2}$ Department of Pharmacy, Sarhad University of Science and Information Technology, Peshawar, KPK, Pakistan. ${ }^{3}$ Department of Chemistry, University of Malakand, Chakdara Dir, KPK, Pakistan.

Received: 2 August 2012 Accepted: 24 November 2012 Published: 5 December 2012

\section{References}

1. Evans WC, Evans D, Trease GE: Trease and Evans Pharmacognosy. Edinburgh, Scotland: Saunders/Elsevier; 2009. ISBN 97780702029332

2. Pohlit AM, Lopes NP, Gama RA, Tadei WP, Neto VF: Patent literature on mosquito repellent inventions which contain plant essential oils-a review. Planta Med 2011, 77(6):598-617.

3. Yildirim A, Cakir A, Mavi A, Yalcin M, Fauler G, Taskesenligil Y. The variation of antioxidant activities and chemical composition of essential oils of Teucrium orientale L. var. orientale during harvesting stages. Flavour and Fragrance J 2004, 19(5):367-372.

4. Ahmad B, Shah SM, Bashir S, Begum H: Antibacterial and antifungal activities of teucrium royleanum (Labiatea). J Enzyme Inhib Med Chem 2008, 23(1):136-139.

5. Fernandez Puntero B, Iglesias Peinado I, del Fresno AM V: Anti-inflammatory and antiulcer activity of Teucrium buxifolium. J Ethnopharmacol 1997, 55(2):93-98.

6. Gharaibeh MN, Elayan HH, Salhab AS: Hypoglycemic effects of Teucrium polium. J Ethnopharmacol 1988, 24(1):93-99.

7. Ahmad B, Mukarram Shah SM, Khan H, Hassan Shah SM: Enzyme inhibition activities of Teucrium royleanum. J Enzyme Inhib Med Chem 2007, 22(6):730-732

8. Tariq M, Ageel AM, al-Yahya MA, Mossa JS, al-Said MS: Anti-inflammatory activity of Teucrium polium. Int J Tissue React 1989, 11(4):185-188.

9. Panovska TK, Kulevanova S, Gjorgoski I, Bogdanova M, Petrushevska G: Hepatoprotective effect of the ethyl acetate extract of Teucrium polium L. against carbontetrachloride-induced hepatic injury in rats. Acta Pharm 2007, 57(2):241-248.

10. Abdollahi M, Karimpour H, Monsef-Esfehani HR: Antinociceptive effects of Teucrium polium $L$ total extract and essential oil in mouse writhing test. Pharmacol Res 2003, 48(1):31-35.

11. Genc GE, Özhatay N: An ethnobotanical study in Çatalca (European part of Istanbul) II. Turk J Pharm Sci 2006, 3(2):73-89.
12. Pieroni $\mathrm{A}$, Quave $\mathrm{CL}$ : Traditional pharmacopoeias and medicines among Albanians and Italians in southern Italy: a comparison. J Ethnopharmacol 2005, 101(1-3):258-270.

13. Da Silva ACR, Lopes PM, De Azevedo MMB, Costa DC, Alviano CS, Alviano DS: Biological activities of alpha-pinene and beta-pinene enantiomers. Molecules 2012, 17(6):6305-6316.

14. Rahim G, Qureshi R, Gulfraz M, Arshad M, Rahim S: Preliminary phytochemical screening and ethnomedicinal uses of Teucrium stocksianum from Malakand Division. J Med Plants Res 2012, 6(5):704-707.

15. Rasheed RA, Ali BH, Bashir AK: Effect of Teucrium stocksianum on paracetamol-induced hepatotoxicity in mice. Gen Pharmacol 1995 26(2):297-301

16. Wasfi IA, Bashir AK, Amiri MH, Abdalla AA, Banna NR, Tanira MOM: Gastric Cytoprotective Activity of Teucrium stocksianum extract in rats. Pharm Biol 1995, 33(2):164-171.

17. Ali N, Shah SW, Shah I, Ahmed G, Ghias M, Khan I: Cytotoxic and anthelmintic potential of crude saponins isolated from Achillea Wilhelmsii C. Koch and Teucrium Stocksianum boiss. BMC Complement Altern Med 2011, 11:106.

18. Collier HO, Dinneen LC, Johnson CA, Schneider C: The abdominal constriction response and its suppression by analgesic drugs in the mouse. Br J Pharmacol Chemother 1968, 32(2):295-310.

19. Bagci E, Yazgın A, Hayta S, Cakılcıoglu U: Composition of the essential Oil of Teucrium chamaedrys L. (Lamiaceae) from Turkey. J Med Plants Res 2010, 4(23):2583-2587.

20. Morteza-Semnani K, Akbarzadeh M, Rostami B: The essential oil composition of Teucrium chamaedrys L. from Iran. Flavour and Fragrance J 2005, 20(5):544-546.

21. Yousuf MHA, Bashir AK, Dobos Á, Veres K, Nagy G, Máthé I, Blunden G: The Composition of the Essential Oil of Teucrium stocksianum from the United Arab Emirates. J Essent Oil Res 2002, 14:47-48.

22. Küçük M, Güleç C, Yaşar A, Üçüncü O, Yaylı N, Coşkunçelebi K, Terzioğlu S, Yaylı N: Chemical Composition and Antimicrobial Activities of the Essential Oils of Teucrium chamaedrys. subsp. chamaedrys., T. orientale var. puberulens., and T. chamaedrys. subsp. lydium. Pharm Biol 2006 44(8):592-599

23. Jaimand K, Rezaee MB, Soltanipoor MA, Mozaffarian V: Volatile Constituents of Teucrium stocksianum Boiss. ssp. stocksianum from Iran. J Essent Oil Res 2006, 18(5):476-477.

24. Moghtader M: Chemical composition of the essential oil of Tecucrium polium L. from Iran. Am-Eurasian J Agric Environ Sci 2009, 5(6):843-846.

25. Ali NAA, Wurster M, Arnold N, Lindequist U, Wessjohan L: Chemical Composition of the Essential Oil of Teucrium yemense Deflers. Rec Nat Prod 2008, 2(2):25-32.

26. Ahmadi L, Mirza M, Shahmir F: Essential Oil of Teucrium melissoides Boiss. et Hausskn. ex Boiss. J Essent Oil Res 2002, 14(5):355-356.

27. Aburjai T, Hudaib M, Cavrini V: Composition of the Essential Oil from Jordanian Germander (Teucrium polium L.). J Essent Oil Res 2006 18(1):97-99

28. Flamini G, Cioni PL, Morelli I, Maccioni S, Monti G: Composition of the essential oil of Teucrium fruticans L. from the Maremma Regional Park (Tuscany, Italy). Flavour and Fragrance J 2001, 16(5):367-369.

29. Cavaleiro C, Salgueiro LR, Antunes T, Sevinate-Pinto I, Barroso JG: Composition of the essential oil and micromorphology of trichomes of Teucrium salviastrum, an endemic species from Portugal. Flavour and Fragrance J 2002, 17(4):287-291.

30. Bulow $N$, Konig WA: The role of germacrene $D$ as a precursor in sesquiterpene biosynthesis: investigations of acid catalyzed, photochemically and thermally induced rearrangements. Phytochemistry 2000, 55(2):141-168.

31. Kiran SR, Devi PS: Evaluation of mosquitocidal activity of essential oil and sesquiterpenes from leaves of Chloroxylon swietenia DC. Parasitol Res 2007, 101(2):413-418

32. Sousa DP: Analgesic-like activity of essential oils constituents. Molecules 2011, 16:2233-2252.

33. Him A, Ozbek H, Turel I, Oner AC: Antinoceceptive activity of alpha-pinen and fenchone. Pharmacologyonline 2008, 3:363-369.

34. Santos FA, Rao VSN, Silveira ER: Investigations on the antinociceptive effect of Psidium guajava leaf essential oil and its major constituents. Phytother Res 1998, 12(1):24-27. 
35. Rao VSN, Menezes AMS, Viana GSB: Effect of myrcene on nociception in mice. J Pharm Pharmacol 1990, 42(12):877-878.

36. do Amaral JF, Silva MI, Neto MR, Neto PF, Moura BA, de Melo CT, de Araujo FL, de Sousa DP, de Vasconcelos PF, de Vasconcelos SM, et al: Antinociceptive effect of the monoterpene $\mathrm{R}$-(+)-limonene in mice. Biol Pharm Bull 2007, 30(7):1217-1220.

37. Peana AT, D'Aquila PS, Chessa ML, Moretti MD, Serra G, Pippia P: (-)-Linalool produces antinociception in two experimental models of pain. Eur J Pharmacol 2003, 460(1):37-41.

38. Chavan MJ, Wakte PS, Shinde DB: Analgesic and anti-inflammatory activity of Caryophyllene oxide from Annona squamosa L. bark. Phytomedicine 2009, 17(2):149-151.

39. Deraedt R, Jouquey S, Delevallee F, Flahaut M: Release of prostaglandins $\mathrm{E}$ and $\mathrm{F}$ in an algogenic reaction and its inhibition. Eur $J$ Pharmacol 1980, 61(1):17-24.

40. Liang J, Huang B, Wang G: Chemical composition, antinociceptive and anti-inflammatory properties of essential oil from the roots of Illicium lanceolatum. Nat Prod Res 2012, 26:1712-1714.

41. Pinheiro BG, Silva AS, Souza GE, Figueiredo JG, Cunha FQ, Lahlou S, da Silva JK, Maia JG, Sousa PJ: Chemical composition, antinociceptive and anti-inflammatory effects in rodents of the essential oil of Peperomia serpens (Sw.). Loud J Ethnopharmacol 2011, 138(2):479-486.

42. Amorim AC, Lima CK, Hovell AM, Miranda AL, Rezende CM: Antinociceptive and hypothermic evaluation of the leaf essential oil and isolated terpenoids from Eugenia uniflora L. (Brazilian Pitanga). Phytomedicine 2009, 16(10):923-928.

43. Baluchnejadmojarad T, Roghani M, Roghani-Dehkordi F: Antinociceptive effect of Teucrium polium leaf extract in the diabetic rat formalin test. J Ethnopharmacol 2005, 97(2):207-210.

doi:10.1186/1472-6882-12-244

Cite this article as: Shah et al: Analysis of chemical constituents and antinociceptive potential of essential oil of Teucrium Stocksianum bioss collected from the North West of Pakistan. BMC Complementary and Alternative Medicine 2012 12:244.

\section{Submit your next manuscript to BioMed Central and take full advantage of:}

- Convenient online submission

- Thorough peer review

- No space constraints or color figure charges

- Immediate publication on acceptance

- Inclusion in PubMed, CAS, Scopus and Google Scholar

- Research which is freely available for redistribution 